J. Environ. Sci.

Institute of Environmental Studies and Research - Ain Shams University

\title{
EFFECT OFVITAMIN D3 IN PATIENTS WITH RESISTANT ASTHMA AMONG CHILDHOOD AND ELDERLY ASTHMATICS
}

\author{
Doaa, S. EL-Shahed ${ }^{(1)}$; Howayda, M. Kamal ${ }^{(2)}$ \\ and Mahmoud, S. El Bokhary ${ }^{(3)}$
}

1) Chest Department, New Cairo Police Hospital 2) Department of Clinical and Chemical Pathology, Faculty of Medicine Benha University 3) Department of Environmental Medical Science, Institute of Environment Studies and Research, Ain Shams University

\begin{abstract}
Background: Bronchial asthma is a chronic inflammatory disorder that is related with hyperresponsiveness of the airways and leads to repeated episodes of wheezing, dyspnea, chest tightness, and cough, which is often reversible, either spontaneously or after treatment Severe, steroid-resistant asthma is clinically and economically important, patients with this disease experience more frequent exacerbations of asthma, and are more likely to be hospitalized, and have a poorer quality of life. The association between vitamin $\mathrm{D}$ deficiency and asthma and allergies has recently increased significantly. Epidemiologic data in most of the reported studies suggest that low serum vitamin D (defined as circulating levels of $25(\mathrm{OH}) \mathrm{D}$ of , $30 \mathrm{ng} / \mathrm{mL}$ ) in children with asthma is associated with more symptoms, exacerbations, reduced lung function, increased medication usage, and severe disease.

The aim of the current study is to evaluate the effect of vitamin D3 in patients with resistant asthma among childhood and elderly asthmatics.

Methods: This study includes 60 Resistant asthmatic subjects including 30 patients with serum 1.25 OH Vitamin D3 deficiency, who will be followed up after VITAMIN D3 supplementation therapy for three months and will be compared with 30 resistant asthmatic subjects with normal serum $1.25 \mathrm{OH}$ Vitamin D3.
\end{abstract}

Results: during the study period 1000 IU Vitamin D3 were supplemented to childhood asthmatics and 2000 IU Vitamin D3 were supplemented to elderly 
resistant asthmatics and Vitamin D3 was measured at the start and the end of the study.

Conclusions: improvement in the pulmonary functions (FEV1, FVC, FEF) especially with those of vitamin D3 deficiency after vitamin D supplementation for 12 weeks.

Recommendation: The study recommend that Measurement of vitamin D must be a routine step in resistant asthma among childhood and elderly resistant asthmatics, Vitamin D supplementation during childhood and adolescence, in adequate doses could be among the national nutritional priorities.

Keywords: Resistant Asthma, Vitamin D3

\section{INTRODUCTION}

According to the Global Initiative for Asthma, bronchial asthma is a chronic inflammatory disorder that is related with hyperresponsiveness of the airways and leads to repeated episodes of wheezing, dyspnea, chest tightness, and cough, particularly at night or early in the morning. These episodes are usually associated with extensive but variable bronchial obstruction, which is often reversible, either spontaneously or after treatment (GINA, 2012).

In the majority of patients control of asthma as defined by guidelines can be achieved with long-term maintenance medications (Brehm et al., 2009). However, a substantial proportion of patients do not achieve optimal asthma control despite even high dose treatment. In particular inadequately controlled patients with severe persistent asthma are at high risk of severe exacerbations and asthma-related mortality. These patients represent the greatest unmet medical need among the asthmatic population today (Freishtat et al., 2010). 
J. Environ. Sci.

Institute of Environmental Studies and Research - Ain Shams University

Although most patients with chronic asthma have significant improvement in their airway function with corticosteroid therapy, a subset of asthmatics are insensitive to corticosteroid (Martin et al., 2007).

Clinical studies have revealed suboptimal response to ICS in about 50\% of asthmatics (Szefler et al., 2010). Failure to detect corticosteroid insensitivity early in the course of illness may affect the treatment strategy and outcome. It should be noted that the term steroid resistant (SR) asthma refer to a relative insensitivity to corticosteroid (Corticosteroid dependent asthma) rather than absolute resistance (Corticosteroid resistant asthma) which is very rare and found in less than 1:1000 asthmatics, about 95\% patients respond well to $\beta 2$ agonist and corticosteroids with or without add on therapies like montelukast and long acting theophyllines. However, 5-10\% of patients do not respond well to this treatment. These cases are labelled as difficult / therapy resistant asthma (Chung et al., 1999).

Corticosteroid resistant asthma is defined as less than $15 \%$ improvement in baseline FEV1 after 14 days course of oral prednisolone (40 mg/day) in patients who demonstrate more than $15 \%$ improvement in FEV1 following the inhaled $\beta 2$ agonist, Salbutamol. Furthermore, the patients who show FEV1 improvement of $30 \%$ or more are considered corticosteroid sensitive (Chung, et al., 2006).

As bronchial asthma is still the most common chronic disease of childhood (Mannino et al., 2002).And one of the leading causes of morbidity in children worldwide (Kunisaki et al., 2012).

The number of studies concerning the association between vitamin D deficiency and asthma and allergies increased significantly. Epidemiologic 
data in most of the reported studies suggest that low serum vitamin D (defined as circulating levels of $25(\mathrm{OH}) \mathrm{D}$ of, $30 \mathrm{ng} / \mathrm{mL}$ ) in children with asthma is associated with more symptoms, exacerbations, reduced lung function, increased medication usage, and severe disease (Bousquet et al., 2000).

Asthmatic airway walls present an accumulation of activated eosinophils lymphocytes, mast cells, macrophages, dendritic cells, and myofibroblasts, which, combined, determine bronchial structural changes and disease progression and severity (van Oosterhout et al., 2005).

Medical therapy involves two different classes of medication - inhaled corticosteroids used as daily controller and beta-adrenergic agonists used for broncho dilation (Dejaco et al., 2006).

Asthma has become one of the most prevalent diseases worldwide causing a major public health concern. While there is evidence that the condition of asthma is multifactorial in etiology, changing environmental factors may underlie the rising prevalence of asthma, such as atmospheric pollution, dietary changes, allergens, improvements in health and hygiene, and lifestyle changes (GINA, 2012).

Among nutritional hypotheses, vitamin D status is of particular interest regarding the controversial beneficial effects in non-skeletal disorders, such as cardiovascular disease, cancer, schizophrenia, multiple sclerosis, and asthma. (Litonjua et al., 2007, Wang, et al., 2008, Toner, et al., 2010, Rosen et al., 2013, Ross et al., 2011). 
Several studies have suggested that vitamin $D$ deficiency and insufficiency are extremely common, even in people with abundant sun exposure (Brehn et al., 2009, Binkley, et al., 2007).

The vitamin D receptor is present in the bronchial smooth muscle (Bosse et al., 2007) and low vitamin D levels may lead to bronchial smooth muscle proliferation, cytokine release and airway remodeling (Damera et al., 2009, Banerjee et al., 2008, Song et al., 2007).

In addition, vitamin $\mathrm{D}$ has been shown to play a role in immunemodulation by interacting with $\mathrm{T}$ lymphocytes, dendritic cells, mast cells, monocytes and macrophages (Sandhu et al., 2010).

Therefore, it is not surprising that vitamin $\mathrm{D}$ deficiency has been associated with airway hyperresponsiveness, lower pulmonary function, and worse asthma control (Black et al., 2005).

The aim of the current study is to evaluate the effect of vitamin D3 in patients with resistant asthma among childhood and elderly asthmatics.

\section{MATERIALS AND METHODS}

This study is observational cohort study conducted at New Cairo Police Hospital, in Chest Department from January 2016 till January 2017 including 60 Resistant Asthmatic subjects including 30 patients with serum $1.25 \mathrm{OH}$ Vitamin D3 deficiency, who will be followed up after VITAMIN D3 supplementation therapy for one month and will be compared with 30 Resistant Asthmatic subjects with normal serum 1.25 OH Vitamin D3. 
Subjects will be grouped into: Group I: 30 Resistant Asthmatic subjects with 1.25 OH Vitamin D3deficiency. Group II: 30 Resistant Asthmatic subjects with normal $1.25 \mathrm{OH}$ Vitamin D3.

All study subjects were recruited on voluntary basis and a written informed consent was obtained from the patients or from the patient's parent or legal guardian when the patient under the age of 18 years.

The following steps may help in the diagnosis of steroid resistant or insensitive asthma (Hartl et al., 2005).

1. Patient should have a prebronchodilator morning FEV $1<70 \%$ of predicted with a $15 \%$ improvement following a rapidly acting bronchodilator treatment. This value of FEV1 is recorded as baseline.

2. These patients should be given oral steroid (prednisolone $40 \mathrm{mg} / \mathrm{day}$ ) for at least two weeks.

3. These patients fail to show increase in prebronchodilator morning FEV1 by $15 \%$ over baseline value even after 2 weeks of oral steroid.

Patients with incorrect diagnosis, non-adherence with therapy and patients with a radiological diagnosis of pneumonia, impaired consciousness on admission or smoking history $>10$ packs/year were excluded from the study.

The steroid resistant asthma should be differentiated from "Brittle asthma", where patient experience recurrent episode of severe airways narrowing that appear rapidly over minute to hours, occurring anytime of the day with no obvious trigger. These patients have either normal lung function between episodes which cannot be prevented by steroid or a persistent 
background of wide variability in airways obstruction. Such episodes may respond to either subcutaneous adrenaline or terbutaline (Gregg et al., 2005).

The following parameters will be performed to patients and control groups: Full history and physical examination. Complete blood count, Erythrocyte sedimentation rate, reticulocytic count. Aspartate transaminase, Alanine transferase, Total bilirubin, Direct bilirubin, Total protein, Serum albumin, Serum creatinine, Blood urea nitrogen, Serum Uric acid. $(1,25 \mathrm{OH}$ VITAMIN D3) Spirometry (FEV1, FVC, FEC1/FVC).

\section{RESULTS}

This study highlights the response to vitamin D3 supplementation as vitamin D deficiency was associated with a decrease in spirometric measures in the Childhood and Elderly resistant asthmatics as shown in the following tables:

Table (1): Demographic comparative analysis between "Cases" and Control:

\begin{tabular}{|c|c|c|c|c|c|}
\hline Variable & $\begin{array}{c}\text { Cases } \\
\text { vitamin D3 } \\
\text { deficiency } \\
(\mathbf{0 - 3 0} \text { ng/mL) } \\
\text { Mean } \pm \text { SD }\end{array}$ & $\begin{array}{c}\text { Control } \\
\text { vitamin } \\
\text { D3sufficiency } \\
\mathbf{( > 3 0 ~ n g / m L ) ~} \\
\text { Mean } \pm \text { SD }\end{array}$ & $\begin{array}{c}\text { T } \\
\text { test(1) }\end{array}$ & $\begin{array}{c}\text { P } \\
\text { Value }\end{array}$ & Significance \\
\hline \hline \multicolumn{7}{|c|}{ Childhood } \\
\hline Age & $13.54 \pm 3.61$ & $15.15 \pm 2.19$ & 0.62 & 0.542 & Non-Significant \\
\hline BMI & $21.22 \pm 1.72$ & $23.21 \pm 1.78$ & 0.57 & 0.573 & Non-Significant \\
\hline $\begin{array}{c}\text { baseline } \\
\text { vit.D } \\
\text { (ng/mL) }\end{array}$ & $11.23 \pm 6.2$ & $43.53 \pm 1.23$ & 3.76 & 0.0004 & Significant \\
\hline \multicolumn{7}{|c|}{ Elderly } \\
\hline Age & $49.12 \pm 9.17$ & $50.35 \pm 8.95$ & 1.24 & 0.224 & Non-Significant \\
\hline BMI & $26.20 \pm 2.25$ & $26.40 \pm 2.95$ & 0.22 & 0.828 & Non-Significant \\
\hline $\begin{array}{c}\text { baseline } \\
\text { vit. D } \\
\text { (ng/mL) }\end{array}$ & $8.76 \pm 4.1$ & $33.64 \pm 1.18$ & 7.48 & 0.0006 & Significant \\
\hline
\end{tabular}


Table 1 shows the study subjects' characteristics at baseline, there was no significant association as regarding age, BMI between "Cases" and "Control «, but there was significant difference as regarding baseline vitamin D (ng/mL) level.

Table (2): Comparative statistical analysis of spirometric measures in "Cases" and "Control "Before oral supplementation with 1000 IU vitamin D3 for children and 2000 IU vitamin D3 for elderly of D3:

\begin{tabular}{|c|c|c|c|c|c|}
\hline Variable & $\begin{array}{c}\text { Cases } \\
\text { Mean } \pm \text { SD }\end{array}$ & $\begin{array}{c}\text { Control } \\
\text { Mean } \pm \text { SD }\end{array}$ & $\begin{array}{c}\text { T } \\
\text { test(1) }\end{array}$ & $\begin{array}{c}\text { P } \\
\text { Value }\end{array}$ & Significance \\
\hline \hline \multicolumn{7}{|c|}{ Childhood } \\
\hline Actual FVC & $2.76 \pm 0.49$ & $2.84 \pm 0.20$ & 0.597 & 0.556 & Non-Significant \\
\hline \%Pred FVC & $75.19 \pm 13.46$ & $81.51 \pm 13.21$ & 1.207 & 0.239 & Non-Significant \\
\hline Actual FEV1 & $1.52 \pm 0.15$ & $1.68 \pm 0.15$ & 2.628 & 0.015 & Significant \\
\hline \%Pred FEV1 & $52.81 \pm 7.38$ & $60.77 \pm 5.76$ & 3.067 & 0.005 & Significant \\
\hline Actual FEF & $0.78 \pm 0.18$ & $0.88 \pm 0.09$ & 1.876 & 0.077 & Non-Significant \\
\hline \%Pred FEF & $25.49 \pm 1.84$ & $26.88 \pm 2.27$ & 1.715 & 0.099 & Non-Significant \\
\hline \multicolumn{7}{|c|}{ Elderly } \\
\hline Actual FVC & $2.57 \pm 0.18$ & $2.67 \pm 0.28$ & 1.266 & 0.216 & Non-Significant \\
\hline \%Pred FVC & $72.51 \pm 14.89$ & $77.94 \pm 9.83$ & 1.257 & 0.219 & Non-Significant \\
\hline Actual FEV1 & $1.50 \pm 0.20$ & $1.67 \pm 0.15$ & 2.766 & 0.009 & Significant \\
\hline \% Pred FEV1 & $52.01 \pm 8.14$ & $58.72 \pm 7.29$ & 2.535 & 0.016 & Significant \\
\hline Actual FEF & $0.77 \pm 0.18$ & $0.85 \pm 0.13$ & 1.552 & 0.131 & Non-Significant \\
\hline \%Pred FEF & $25.51 \pm 2.54$ & $26.57 \pm 0.80$ & 1.664 & 0.119 & Non-Significant \\
\hline
\end{tabular}

Table 2 shows significant association between "Cases" and "Control

"Before oral supplementation with 1000 IU vitamin of D3 in Childhood and 2000 IU Elderly Resistant Asthmatics as regarding the mean "Actual FEV1\% and Predictive FEV1" while there was non significant association as regarding the other spirometric measures. 
J. Environ. Sci.

Institute of Environmental Studies and Research - Ain Shams University

Table(3): Comparative statistical analysis of spirometric measures in "Cases" and

"Control" after oral supplementation with 1000 IU vitamin D3 for

children and 2000 IU vitamin D3 for elderly from day 1 to day 90:

\begin{tabular}{|c|c|c|c|c|c||}
\hline Variable & $\begin{array}{c}\text { Cases } \\
\text { Mean } \pm \text { SD }\end{array}$ & $\begin{array}{c}\text { Control } \\
\text { Mean } \pm \text { SD }\end{array}$ & $\begin{array}{c}\text { T } \\
\text { test(1) }\end{array}$ & $\begin{array}{c}\text { P } \\
\text { Value }\end{array}$ & Significance \\
\hline \hline \multicolumn{7}{|c|}{ Childhood } \\
\hline Actual FVC & $3.08 \pm 0.33$ & $2.89 \pm 0.18$ & 1.737 & 0.099 & Non-Significant \\
\hline \%Pred FVC & $82.01 \pm 10.78$ & $81.53 \pm 12.24$ & 0.107 & 0.916 & Non-Significant \\
\hline Actual FEV1 & $1.72 \pm 0.18$ & $1.69 \pm 0.13$ & 0.609 & 0.548 & Non-Significant \\
\hline \%Pred FEV1 & $60.51 \pm 8.41$ & $60.79 \pm 5.17$ & 0.099 & 0.922 & Non-Significant \\
\hline Actual FEF & $1.42 \pm 0.25$ & $1.51 \pm 0.23$ & 0.954 & 0.350 & Non-Significant \\
\hline \%Pred FEF & $43.28 \pm 7.38$ & $44.09 \pm 5.87$ & 0.307 & 0.761 & Non-Significant \\
\hline \multicolumn{7}{|c|}{ Elderly } \\
\hline Actual FVC & $2.98 \pm 0.36$ & $2.82 \pm 0.16$ & 1.714 & 0.100 & Non-Significant \\
\hline \%Pred FVC & $83.10 \pm 8.70$ & $77.95 \pm 8.37$ & 1.760 & 0.088 & Non-Significant \\
\hline Actual FEV1 & $1.82 \pm 0.11$ & $1.75 \pm 0.16$ & 1.601 & 0.120 & Non-Significant \\
\hline \%Pred FEV1 & $59.70 \pm 7.61$ & $58.72 \pm 6.99$ & 0.338 & 0.701 & Non-Significant \\
\hline Actual FEF & $1.34 \pm 0.26$ & $1.36 \pm 0.38$ & 0.139 & 0.90 & Non-Significant \\
\hline \%Pred FEF & $43.93 \pm 9.84$ & $43.58 \pm 6.70$ & 0.120 & 0.906 & Non-Significant \\
\hline \hline
\end{tabular}

Table 3 shows no significant association in spirometric measures between "Cases" and "Control" after oral supplementation with $1000 \mathrm{IU}$ vitamin D3 for children and 2000 IU vitamin D3 for elderly from day 1 to day 90. 
Table(4): Comparative spirometric analysis in "Control" before and after oral supplementation with 1000 IU vitamin D3 for children and 2000 IU vitamin D3 for elderly from day 1 to day 90:

\begin{tabular}{|c|c|c|c|c|c||}
\hline Variable & $\begin{array}{c}\text { Cases } \\
\text { Mean } \pm \text { SD }\end{array}$ & $\begin{array}{c}\text { Control Mean } \\
\pm \text { SD }\end{array}$ & $\begin{array}{c}\text { T } \\
\text { test(1) }\end{array}$ & $\begin{array}{c}\text { P } \\
\text { Value }\end{array}$ & Significance \\
\hline \hline \multicolumn{7}{|c||}{ Childhood } \\
\hline Actual FVC & $2.84 \pm 0.20$ & $2.89 \pm 0.18$ & 1.539 & 0.150 & Non-Significant \\
\hline \%Pred FVC & $81.51 \pm 13.21$ & $81.53 \pm 12.24$ & 0.020 & 0.984 & Non-Significant \\
\hline Actual FEV1 & $1.68 \pm 0.15$ & $1.69 \pm 0.13$ & 0.160 & 0.876 & Non-Significant \\
\hline \%Pred FEV1 & $60.77 \pm 5.76$ & $60.79 \pm 5.17$ & 0.010 & 0.993 & Non-Significant \\
\hline Actual FEF & $0.88 \pm 0.09$ & $1.51 \pm 0.23$ & 9.732 & 0.000 & Significant \\
\hline \%Pred FEF & $26.88 \pm 2.27$ & $44.09 \pm 5.87$ & 11.348 & 0.000 & Significant \\
\hline \multicolumn{7}{|c|}{ Elderly } \\
\hline Actual FVC & $2.67 \pm 0.28$ & $2.82 \pm 0.16$ & 2.008 & 0.062 & Non-Significant \\
\hline \%Pred FVC & $77.94 \pm 9.83$ & $77.95 \pm 8.37$ & 0.001 & 0.999 & Non-Significant \\
\hline Actual FEV1 & $1.67 \pm 0.15$ & $1.75 \pm 0.16$ & 1.838 & 0.085 & Non-Significant \\
\hline \%Pred FEV1 & $58.72 \pm 7.29$ & $58.72 \pm 6.99$ & 0.004 & 0.997 & Non-Significant \\
\hline Actual FEF & $0.85 \pm 0.13$ & $1.36 \pm 0.38$ & 7.836 & 0.000 & Significant \\
\hline \%Pred FEF & $26.57 \pm 0.80$ & $43.58 \pm 6.70$ & 11.075 & 0.000 & Significant \\
\hline
\end{tabular}

Table 4 shows significant association in "Control" before and after oral supplementation with 1000 IU vitamin D3 for children and 2000 IU vitamin D3 for elderly from day 1 to day 90 in Childhood and Elderly Resistant Asthmatics as regarding the mean "Actual and Predictive FEF " while there was non-significant association as regarding the other spirometric measures. 
J. Environ. Sci.

Institute of Environmental Studies and Research - Ain Shams University

Table(5): Comparative spirometric analysis in "Cases" before and after oral supplementation with 1000 IU vitamin D3 for children and 2000 IU vitamin D3 for elderly from day 1 to day 90:

\begin{tabular}{|c|c|c|c|c|c||}
\hline Variable & $\begin{array}{c}\text { Cases } \\
\text { Mean } \pm \text { SD }\end{array}$ & $\begin{array}{c}\text { Control } \\
\text { Mean } \pm \text { SD }\end{array}$ & $\begin{array}{c}\text { T } \\
\text { test(1) }\end{array}$ & P Value & Significance \\
\hline \multicolumn{7}{|c||}{ Childhood } \\
\hline Actual FVC & $2.76 \pm 0.49$ & $3.08 \pm 0.33$ & 2.882 & 0.014 & Significant \\
\hline \%Pred FVC & $75.19 \pm 13.46$ & $82.01 \pm 10.78$ & 5.576 & 0.0001 & Significant \\
\hline Actual FEV1 & $1.52 \pm 0.15$ & $1.72 \pm 0.18$ & 3.908 & 0.0021 & Significant \\
\hline \%Pred FEV1 & $52.81 \pm 7.38$ & $60.51 \pm 8.41$ & 7.534 & 0.000007 & Significant \\
\hline Actual FEF & $0.78 \pm 0.18$ & $1.42 \pm 0.25$ & 23.481 & 0.000 & Significant \\
\hline \%Pred FEF & $25.49 \pm 1.84$ & $43.28 \pm 7.38$ & 10.985 & 0.000 & Significant \\
\hline \multicolumn{7}{|c|}{ Elderly } \\
\hline Actual FVC & $2.57 \pm 0.18$ & $2.98 \pm 0.36$ & 4.769 & 0.0002 & Significant \\
\hline \%Pred FVC & $72.51 \pm 14.89$ & $83.10 \pm 8.70$ & 4.786 & 0.0002 & Significant \\
\hline Actual FEV1 & $1.50 \pm 0.20$ & $1.82 \pm 0.11$ & 6.297 & 0.00001 & Significant \\
\hline \%Pred FEV1 & $52.01 \pm 8.14$ & $59.70 \pm 7.61$ & 6.211 & 0.00001 & Significant \\
\hline Actual FEF & $0.77 \pm 0.18$ & $1.34 \pm 0.26$ & 8.566 & 0.0000002 & Significant \\
\hline \%Pred FEF & $25.51 \pm 2.54$ & $43.93 \pm 9.84$ & 8.144 & 0.0000004 & Significant \\
\hline
\end{tabular}

Table (5) shows that there is significant association in"Cases" before and after oral supplementation with 1000 IU vitamin D3 for children and 2000 IU vitamin D3 for elderly from day 1 to day 90 as regarding all spirometric measures "Actual and Predictive FEV1, FVC,FEF". 
Table(6): Comparative spirometric analysis (change) in "Cases" and "Control" before and after oral supplementation with 1000 IU vitamin D3 for children and 2000 IU vitamin D3 for elderly from day 1 to day 90:

\begin{tabular}{|c|c|c|c|c|c|}
\hline Variable & $\begin{array}{c}\text { Cases } \\
\text { Mean } \pm \text { SD }\end{array}$ & $\begin{array}{c}\text { Control } \\
\text { Mean } \pm \text { SD }\end{array}$ & $\begin{array}{c}\text { T } \\
\text { test }(1)\end{array}$ & P Value & Significance \\
\hline \hline \multicolumn{7}{|c|}{ Childhood } \\
\hline FVC\% change & $6.82 \pm 4.41$ & $0.02 \pm 4.06$ & 4.088 & 0.0004 & Significant \\
\hline FEV1\% change & $7.71 \pm 3.69$ & $0.02 \pm 5.79$ & 4.041 & 0.0005 & Significant \\
\hline FEF\% change & $17.79 \pm 5.84$ & $17.20 \pm 5.47$ & 0.266 & 0.793 & Non-Significant \\
\hline \multicolumn{7}{|c|}{ Elderly } \\
\hline FVC\% change & $10.59 \pm 9.12$ & $0.00 \pm 3.54$ & 4.462 & 0.00009 & Significant \\
\hline FEV1\% change & $7.69 \pm 5.11$ & $0.00 \pm 3.54$ & 5.104 & 0.00001 & Significant \\
\hline FEF\% change & $18.42 \pm 9.32$ & $17.02 \pm 6.33$ & 0.512 & 0.612 & Non-Significant \\
\hline
\end{tabular}

Table 6 shows that there is significant association in the (change) in "Cases" and "Control" before and after oral supplementation with $1000 \mathrm{IU}$ vitamin D3 for children and 2000 IU vitamin D3 for elderly from day 1 to day 90 in $\mathrm{FEV} 1 \%$ change and $\mathrm{FVC} \%$ change and there was non-significant association as regarding FEF\% change.

\section{DISCUSSION}

In the present study we investigated the role of vitamin D in a group of children and elderly subjects with asthma. Similar to our study, a systematic review and meta-analysis incorporated evidence from 435 child and 658 adults participating in nine double-blind, randomised, placebo-controlled trials of vitamin D supplementation, of these, one trial involving 22 children and two trials involving 658 adults contributed to the analysis of the rate of exacerbations requiring systemic corticosteroids. Administration of vitamin D resulted in a clinically and statistically significant reduction in the rate of 
J. Environ. Sci.

Institute of Environmental Studies and Research - Ain Shams University

asthma exacerbations requiring treatment with systemic corticosteroids (Martineau et al., 2016).

\section{CONCLUSION}

This study highlights the response to vitamin D3 supplementation as vitamin D deficiency was associated with a decrease in spirometric measures in the Childhood and Elderly resistant asthmatics. However, there is still need to evaluate this effect of vitamin D3 in patients with resistant asthma among childhood and elderly asthmatics through further studies.

\section{RECOMMENDATIONS}

Measurement of vitamin D must be a routine step in resistant asthma among childhood and elderly asthmatics. Vitamin D supplementation during childhood and adolescence, in adequate doses could be among the national nutritional priorities.

\section{REFERENCES}

Afshar, R; Medoff, B. D. and Luster A. D. (2008): "Allergic asthma: a tale of many T cells.” ClinExp Allergy, 38:1847-57.

Binkley, N. ; Novotny, R. ; Krueger, D. ; Kawahara, T. ; Daida, Y. G. ; Lensmeyer, G. ; Hollis, B. W. and Drezner, M.K. (2007): "Low vitamin D status despite abundant sun exposure." J ClinEndocrinolMetab, 92:2130-2135.

Black, P. N. and Scragg, R. (2005): "Relationship between serum 25hydroxyvitamin $\mathrm{D}$ and pulmonary function in the third national health and nutrition survey." Chest, 128:3792-3798. 
Bosse, Y. ; Maghni, K. and Hudson T. J. (2007): "1 $\alpha$, 25-dihydroxyvitamin D3 stimulation of bronchial smooth muscle cells induces autocrine, contractility and remodeling processes." Physiol Genomics, 29:161-168.

Bousquet, J.; Jeffery, PK; Busse, W. W. ; Johnson, M.and Vignola, A. M. (2000): "Asthma. From bronchoconstriction to airways inflammation and remodeling. " A. $m$ J RespirCrit Care Med,161:1720-45.

Brehm, J. M. ; Celedo’n, J. C. ; Soto-Quiros, ME; Avila, L.; Hunninghake G. M.and Forno E. (2009): "Serum vitamin D. levels and markers of severity of childhood asthma in Costa Rica. " Am J RespirCrit Care Med, 179:765-71.

Brehm, J. M. ; Celedon, J. C. ; Soto-Quiros, M. E. ; Avila, L. ; Hunninghake, GM; Forno, E. ; Laskey, D. ; Sylvia, JS; Hollis, B. W. ; Weiss, S. T..and Litonjua A. A. (2009): "Serum vitamin D levels and markers of severity of childhood asthma in Costa Rica." Am J. RespirCrit Care Med, 179:765- 771. http:// www. ncbi.nlm.nih.gov/pubmed/ 19179486. Accessed August 29, 2016.

Bryl, E. and Witkowski J. M. (2004): "Decreased proliferative capability of CD4 (+) cells of elderly people is associated with faster loss of activation-related antigens and accumulation of regulatory $\mathrm{T}$ cells." ExpGerontol, 39(4):587-95.

Chung, K. F. and Adcock, I. M. (2006): "Update on glucocorticoid action and resistance. J Allergy.” ClinImmunol, 117:522-543.

Chung, K. F. ; Godard, P. ; Adelroth, E. ; Ayres, J.; Barnes, Nand Barnes P . (1999): "Difficult / Therapy resistant Asthma." EurRespir J, 13:1198-1208.

Damera, G., Fogle, H. ; Goncharova, E. A. ; Goncharova, E. A. ; Zhao, H. ; Krymskaya, VP.and Panettieri R. A. (2009): "Vitamin D attenuates growth factor-induced human airway smooth muscle cell proliferation." American Thoracic Society (ATS), 117:27222723 . 
Banerjee, A. ; Damera, G. ; Bhandere, R. ; Gu S. ; Lopez-Boado, Y. S,.and Tliba, O. (2008): "Vitamin D and glucocorticoids differentially modulate chemokine expression in human airway smooth muscle cells.” Br J Pharmacol, 155:84-92.

Dejaco, C. ; Duftner, C .and Schirmer, M. (2006): "Are regulatory T-cells linked with aging?” ExpGerontol, 41(4):339-45.

Flores, K. G. ; L. i, J. ; Sempowski, G. D. ; Haynes, B. F , and Hale, L. P. (1999): "Analysis of the human thymic perivascular space during aging." J Clin Invest, 104:1031-9.

Freishtat, R. J, Iqbal, S. F; Pillai, D. K; Klein, C. J; Ryan, L. M; Benton, A. S. and Teach, S. J. (2010): "High prevalence of vitamin D deficiency among inner-city African American youth with asthma in Washington.” DC. J Pediatr, 156:948-952.

Global Initiative for Asthma. (2010): "GINA Report, Global Strategy for Asthma Management and Prevention". Available at: [www.ginasthma.org]. Accessed August 29, 2016.

Global Initiative for Asthma. (2012): “GINA Report. Global Initiative for Asthma (GINA). Available at: [www.ginasthma.org]. Accessed August 29, 2016.

Gregg, R. ; Smith, C. M; Clark, F. J. ; Dunnion, D. ; Khan, N. ; Chakraverty, R; Nayak, L .and Moss, P. A. (2005): "The number of human peripheral blood CD4+ CD25high regulatory $\mathrm{T}$ cells increases with age." ClinExpImmunol, 140(3):540-6.

Hanania, N. A., King, M. J; Braman, S. S; Saltoun, C. ; Wise, R. A; Enright, P; Falsey, A. R; Mathur, S. K; Ramsdell, J. W; Rogers, L. ; Stempel, D. A. ; Lima, J. J; Fish, J. E; Wilson, S. R; Boyd, C. ; Patel, K. V; Irvin, C. G; Yawn, B. P; Halm, E. A; Wasserman, S. I. ; Sands, M. F. ; Ershler, W. B. and Ledford, D. K. (2011): “ Asthma in the elderly: current understanding and future research needs - a report of a National Institute on Aging (NIA) workshop."J Allergy ClinImmunol, 128:S4-S24.

Hartl, D. ; Koller, B. ; Mehlhorn, A. T. ; Reinhardt, D. ; Nicolai, T. ; Schendel, D. J. ; Griese, M. and Krauss-Etschmann, S. (2007): 
"Quantitative and functional impairment of pulmonary CD4+CD25hi regulatory T cells in pediatric asthma." J Allergy ClinImmunol, 119:1258-66.

Hwang, K. A. ; Kim, H. R. and Kang, I. (2009): “Aging and human CD4 (1) regulatory T cells.” Mech Ageing Dev,130:509-17.

Kunisaki, K. M. ; Niewoehner, D. E. and Connett, J. E. (2012): “COPD Clinical Research Network. Vitamin D levels and risk of acute exacerbations of chronic obstructive pulmonary disease: a prospective cohort study."Am J RespirCrit Care Med, 185(3):286-290.

Litonjua, A. A .and Weiss, S. T. (2007): "Is vitamin D deficiency to blame for the asthma epidemic?" J Allergy ClinImmunol,120(5):10311035 .

Mannino, D. M. ; Homa, D. M. ; Akinbami, L. J. ; Moorman, JE; Gwynn, C. and Redd, S. C. (2002): "Surveillance for asthma - United States, 1980-1999.” MMWR SurveillSumm, 51(1):1-13.

Martin, R. J. ; Szefler, S. J. ; King, T. S. ; Kraft, M. ; Boushey, H. A. and Chinchilli, VM. (2007): "The predicting response to inhaled corticosteroids efficacy (PRICE) trial." J Allergy Clin Immunol,119:73-80

Martineau, A. R. ; Cates, C. J. ; Urashima, M. ; Jensen, M. ; Griffiths, A. P. ; Nurmatov, U.; Sheikh, A. ; Griffiths, C. J. and Stefanidis, C. (2016): " Vitamin D for the management of asthma." Cochrane Database of Systematic Reviews; Issue 9. Art. No.: CD011511

Masoli, M. ; Fabian, D. ; Holt, S. .and Beasley, R. (2004): “Global Initiative for Asthma (GINA) Program. The global burden of asthma: executive summary of the GINA Dissemination Committee report." Allergy, 59(5):469-478.

Rosen, C. J. ; Adams, J. S. and Bikle, D. D. (2012): "The nonskeletal effects of vitamin D: an Endocrine Society scientific statement." Endocr Rev, 33(3):456-492. 
Ross, A. C. ; Manson, JE .and Abrams, S. A. (2011): "The 2011 report on dietary reference intakes for calcium and vitamin D from the Institute of Medicine: what clinicians need to know."JClinEndocrinolMetab; 96(1):53-58.

Salas, N.M.; Lio, L and Harkins, M. S. (2014): "Vitamin D deficiency and adult asthma exacerbations.”J Asthma, 2: 1-6.

Sandhu, M. S and Casale, T. B. (2010): "The role of vitamin D in asthma."Ann Allergy Asthma Immunol, 105:191-199.

Song, Y. ; Q. i., H .and W. u, C. (2007): "Effect of 1, 25-(OH) 2D3 (a vitamin $\mathrm{D}$ analogue) on passively sensitized human airway smooth muscle cells." Respirology, 12:486-494.

Szefler, S. J .and Martin, R. J. (2010): "Lessons learned from variation in response to therapy in clinical trials."J Allergy ClinImmunol, 125:285-294.

Toner, C. D., Davis, C. D .and Milner, J. A. (2010): "The vitamin D and cancer conundrum: aiming at a moving target."J Am Diet Assoc; 110(10): 1492-1500.

Van Oosterhout, A. J and Bloksma, N. (2005): "Regulatory T-lymphocytes in asthma." EurRespir J,26(5):918-32

Wang, T. J. ; Pencina, M. J .and Booth, S. L. (2008): "Vitamin D deficiency and risk of cardiovascular disease." Circulation, 117(4):503-511. 


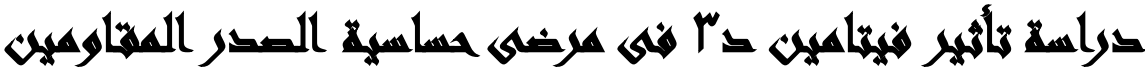

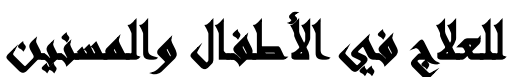

[०]

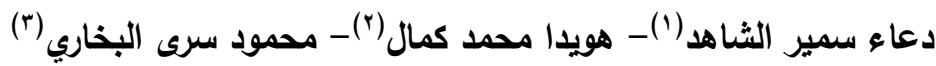

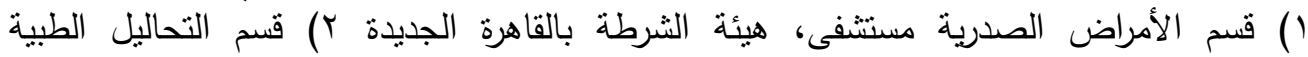
الإكلينيكية، كلية الطب، جامعة بنها r) قسم العلوم الطبية البيئية، معهد الدراسات والبحوث البئية البئية

\section{المستخلم}

يمثل الربو واحدا من أكثر الأمراض المزمنة شيوعا ويشكل مشكلة صحية عامة رئيسية في

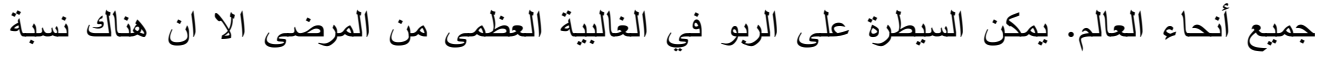

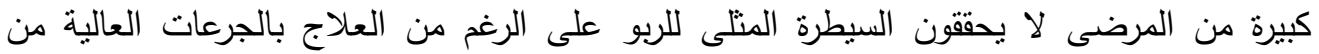

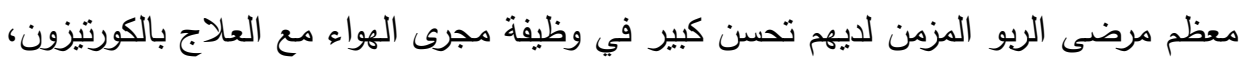

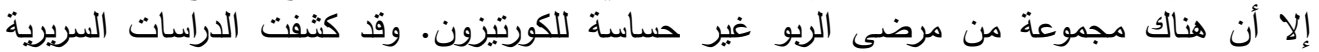

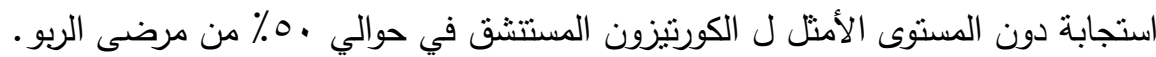

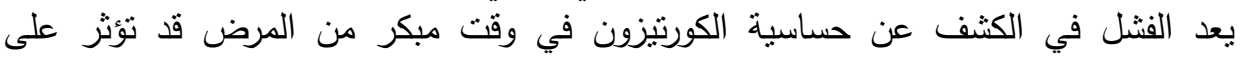

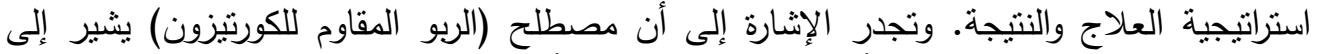

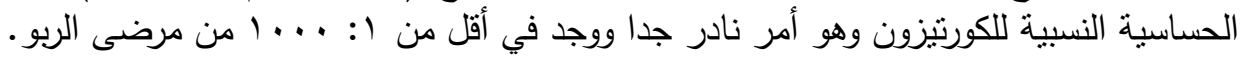

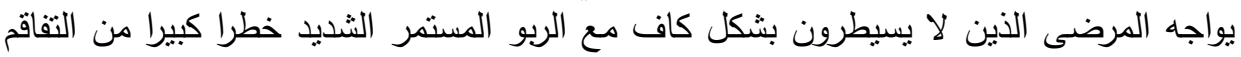

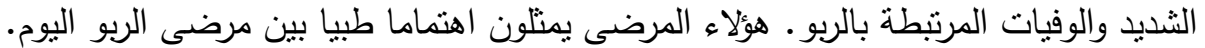

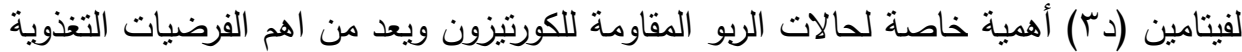

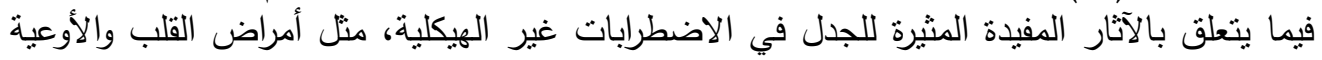

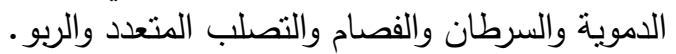

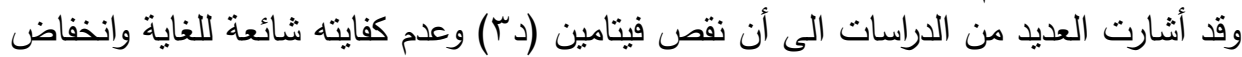

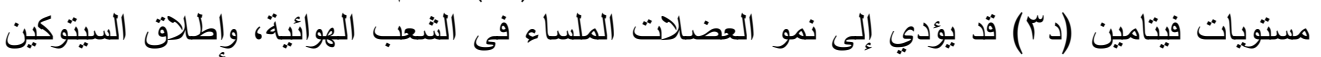

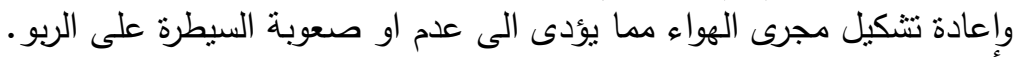

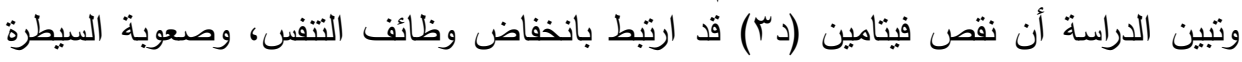
على الربو في الاطفال والمسنين. 